\title{
Effects of protein supplementation on resistance and resilience of lambs naturally infected with gastrointestinal parasites
}

\section{Efeitos da suplementação de proteínas na resistência e resiliência de cordeiros naturalmente infectados com parasitas gastrointestinais}

\author{
Josiane Batista Mendes ${ }^{1}$; Maria Christine Rizzon Cintra ${ }^{1}$; \\ Lígia Valéria Nascimento ${ }^{1}$; Rebecca Mayre Miranda de Jesus' ${ }^{2}$; Dhéri Maia ${ }^{1}$; \\ André Ostrensky ${ }^{3}$; Valéria Natascha Teixeira ${ }^{3}$; Cristina Santos Sotomaior ${ }^{4 *}$
}

\begin{abstract}
In this study, the objective was to evaluate the efficacy of protein supplementation on gastrointestinal nematode control in lambs naturally infected. Sixty weaned Ile de France and Texel crossbred lambs, with 60 days of age, were divided into three groups $(n=20)$ according to the level of protein in the concentrate: low protein (LP; 8.5\%), moderate protein (MP; 15\%), and high protein (HP; 25\%). The daily amount of concentrate offered was based on $3 \%$ of live weight, which was continued throughout the experiment of 98 days. Evaluations were conducted biweekly from days 0 (D0) to 98 (D98). There were no significant differences $(\mathrm{p}>0.05)$ in the average weight among the LP, MP and HP groups, which was $22.0,21.4$, and $21.1 \mathrm{~kg}$, respectively, on D0 and 46.4, 48.3, and $48.2 \mathrm{~kg}$, respectively, on D98. The daily weight gain was not significantly different among the groups (LP, $250 \mathrm{~g}$; MP and HP, 276 $g ; p>0.05)$. The average egg count per gram of feces (epg) of the LP group on D98 $(6,765$; an increase of 5,690 epg from D0) was higher than that of the MP and HP groups $(1,617.5, p<0.05$ and 3,435, p $>0.05$, respectively), which remained constant throughout the study. The hematocrit values decreased $(\mathrm{p}<0.05)$ from D0 to D98 only in the LP group. Only in the HP group $(\mathrm{p}<0.05)$, the mean serum total protein concentration increased from D0 $\left(5.3 \mathrm{~g} \mathrm{dL}^{-1}\right)$ to $\mathrm{D} 98\left(5.8 \mathrm{~g} \mathrm{dL}^{-1}\right)$. The average albumin level on D98 $\left(2.10 \mathrm{~g} \mathrm{dL}^{-1}\right)$ was lower than that on D0 $\left(2.52 \mathrm{~g} \mathrm{dL}^{-1}\right)$ in the LP group $(\mathrm{p}<0.05)$. During the study, 10 lambs overall were treated with anthelmintic because the epg values exceeded 10,000; six treated lambs were from the LP group, 3 from the HP group, and only 1 from the MP group. These results indicate that supplementation of diet with $15 \%$ protein increases the resistance and resilience of lambs to gastrointestinal parasites.
\end{abstract}

Key words: Haemonchus contortus. Host resistance. Protein supplementation. Resilience. Sheep production.

\section{Resumo}

O objetivo deste estudo foi avaliar a eficácia da suplementação de proteínas no controle de nematoides gastrointestinais em cordeiros naturalmente infectados. Foram utilizados 60 cordeiros desmamados, com 60 dias de idade, mestiços Ile de France e Texel, divididos em três grupos $(n=20)$ de acordo com

\footnotetext{
${ }^{1}$ Discentes, Programa de Pós-Graduação em Ciência Animal, PPGCA, Pontifícia Universidade Católica do Paraná, PUCPR, Curitiba, PR, Brasil. E-mail: josiane.mendes@pucpr.br; mary.rizzon89@gmail.com; ligiavaleria.nascimento@gmail.com; dherimaia@hotmail.com

2 Discente, Curso de Medicina Veterinária, PUCPR, Curitiba, PR, Brasil. E-mail: rebecca.mayre@hotmail.com

3 Profs., Curso de Medicina Veterinária, PUCPR, Curitiba, PR, Brasil. E-mail: andreost@terra.com.br; valeria.natascha@pucpr.br

${ }^{4}$ Prof ${ }^{a}$, Programa de Pós-Graduação em Ciência Animal, PPGCA, PUCPR, Curitiba, PR, Brasil. E-mail: cristina.sotomaior@ pucpr.br

* Author for correspondence
} 
o nível de proteína no concentrado: proteína baixa (PB; 8,5\%), proteína moderada (PM; $15 \%)$ e alta proteína (AP; $25 \%$ ). A quantidade diária de concentrado oferecida foi baseada em $3 \%$ do peso vivo, que se manteve ao longo do período experimental de 98 dias. As avaliações foram realizadas quinzenalmente a partir do dia 0 (D0) ao dia 98 (D98). Não houve diferença ( $\mathrm{p}>0,05)$ no peso médio dos grupos BP, MP e AP, iniciando em D0 com 22,0 kg, 21,4 kg e 21,1 kg, e finalizando em D98 com 46,4 kg, 48,3 kg, $48,2 \mathrm{~kg}$, respectivamente. Não houve diferença significativa $(\mathrm{p}>0,05)$ no ganho médio de peso diário entre os diferentes grupos (PB, $250 \mathrm{~g}$; PM e AP, $276 \mathrm{~g}$ ). A contagem média de ovos por grama de fezes (opg) do grupo PB no D98 (6.665 opg, aumento de 5.690 opg em relação ao D0) foi maior que a dos grupos PM e AP (1.617,5, p < 0,05 e 3.435, p > 0,05, respectivamente), que permaneceu constante ao longo do estudo. Os valores de hematócrito diminuíram $(\mathrm{p}<0,05)$, do D0 para D98, apenas no grupo PB. Somente no grupo AP $(p<0,05)$, a concentração sérica de proteína total aumentou do D0 $(5,3$ $\left.\mathrm{g} \mathrm{dL}^{-1}\right)$ para D98 $\left(5,8 \mathrm{~g} \mathrm{dL}^{-1}\right)$. O nível médio de albumina no D98 $\left(2,10 \mathrm{~g} \mathrm{dL}^{-1}\right)$ foi menor do que no D0 $\left(2,52 \mathrm{~g} \mathrm{dL}^{-1}\right)$ no grupo PB $(\mathrm{p}<0,05)$. Durante o estudo, 10 cordeiros no total foram tratados com antihelmínticos, pois os valores de opg excederam 10.000; seis cordeiros tratados eram do grupo PB, três do grupo AP e apenas um do grupo PM. Estes resultados indicam que a suplementação com $15 \%$ de proteína aumenta a resistência e a resiliência dos cordeiros aos parasitas gastrointestinais.

Palavras-chave: Haemonchus contortus. Resistência do hospedeiro. Suplementação de proteínas. Resiliência. Produção de ovinos.

\section{Introduction}

Because of widespread anthelmintic resistance (THOMAZ-SOCCOL et al., 2004; PAPADOPOULOS, 2008; TORRES-ACOSTA et al., 2012a; ROSE et al., 2015), with cases even reported to monepantel (SCOTT et al., 2013; VAN DEN BROM et al., 2015; CINTRA et al., 2016), the control of internal parasites must currently focus on the application of Integrated Parasite Management (IPM), which combines chemical and nonchemical approaches (HOSTE; TORRES-ACOSTA, 2011; KAHN; WOODGATE, 2012).

Management practices that manipulate nutrition to improve host resilience and/or resistance to infection could be one of the components in this integrated approach, because nutrition influences host/parasite interactions. With nutrient supplementation, host resistance to gastrointestinal nematodes (GINs) can increase, because when nutrients are scarce, many functions are inhibited, including immune functions, which regulate the establishment, fecundity, and survival of GINs within the host (COOP; KYRIAZAKIS, 1999; TORRES-ACOSTA et al., 2012b). Host nutrition potentially affects the establishment of GIN infection by affecting innate immunity and the rate of acquisition and degree of expression of immunity
(COOP; KYRIAZAKIS, 1999). Additionally, host resistance to GINs is likely more sensitive to protein scarcity than to energy shortage (HOUDIJK, 2012).

According to Bishop and Stear (2003), resistance to infection is essentially the ability of a host to interact with and control the life cycle of the parasite, whereas resilience is the ability of a host to maintain a reasonable level of productivity under a parasitic challenge (ALBERS et al., 1987). Therefore, the measurement of resistance to infection with GINs in sheep is usually based on the fecal egg count (FEC) or worm burden (BISHOP, 2012; KELLY et al., 2013). However, far less agreement exists on the measures of resilience to GINs and in their application. In an environment characterized by infection with the hematophagous parasite Haemonchus contortus, resilience was defined as the ability to maintain body growth or hematocrit levels when infected (KELLY et al., 2013). The frequency of required anthelmintic treatment can also be considered a measure of resilience (BISHOP, 2012).

Most experiments concerning protein supplementation are with lambs experimentally infected with $H$. contortus (DATTA et al., 1999; STRAIN; STEAR, 2001; HAILE et al., 2004; BRICARELLO et al., 2005; KHAN et al., 2012; CARVALHO et al., 2015). The objective of this 
study was to evaluate the effects of different levels of protein supplementation on the resistance and resilience of lambs naturally infected with GINs by analyzing parasitological, productivity, hematological, and biochemical parameters.

\section{Material and Methods}

\section{Ethics statement}

Our group from the Pontifícia Universidade Católica do Paraná (PUCPR), Fazenda Rio Grande, Paraná, Brazil, conducted this study between July 2013 and February 2014 in the Ovine Sector of the Experimental Farm Gralha Azul. The Research Ethics Committee of PUCPR, under protocol 801, approved this study.

\section{Experimental design}

Sixty total Ile de France and Texel crossbred lambs born between May and September 2013 were used in this study. The lambs and the mothers stayed in paddocks of ryegrass and native pasture during the day, from 10 days after birth to weaning. At the barn, the lambs had access to a concentrate in the creep feeder. All lambs were weighed weekly from birth. Upon reaching $20 \mathrm{~kg}$ of body weight and at least 45 days of age, lambs were weaned and vaccinated against clostridial diseases $\left(\right.$ Sintoxan $^{\circledR}$ Polivalente T, Merial, Brazil).

After weaning, an adaptation period of one week followed before the start of the experiment. During this period, all animals were confined to experimental pens and received feed concentrate with $15 \%$ crude protein (CP), in addition to ad libitum access to grass hay and water. Then, the lambs were divided into three groups $(\mathrm{n}=20$ in each group) according to the level of protein supplement in their concentrate: low protein (LP; 8.5\%), moderate protein (MP; 15\%), and high protein (HP; 25\%). The three groups were homogenous in composition, with the same proportions of male and female animals and similar values of initial weight and FEC. To compare possible low and high levels of infection, half of the lambs $(n=10)$ of each group were treated with an anthelmintic $(2.5 \mathrm{mg}$ $\mathrm{kg}^{-1}$ monepantel; Zolvix ${ }^{\circledR}$, Novartis Saúde Animal, Brazil) at weaning (lot A). For the other 10 lambs of each group (lot B), no anthelmintic treatment was administered at weaning.

Throughout the experiment, the lambs all grazed together in paddocks of native pasture (low protein level) during the day and at the end of the day, were housed in collective pens. Three collective pens were used, one for each experimental group (LP, $\mathrm{MP}$, and HP).

Evaluations were conducted biweekly from days 0 (D0) to 98 (D98) and included parameters of productivity [live weight (LW) and daily weight gain (DWG)], a parasitological (FEC) and a hematological parameter [hematocrit $(\mathrm{Ht})$ level], and biochemical parameters (total serum protein, albumin, globulins, and urea levels). The evaluations and sample collections were all performed at the same time, $08 \mathrm{~h} 30$, when the animals were fasting and had not yet been fed.

Throughout the experiment, lambs identified with FEC greater than 10,000 eggs per gram (epg) were treated with the anthelmintic, regardless of the lot, diet group, or time point.

\section{Experimental diets}

The diets were formulated in accordance with the recommendations of Nutrient Requirements of Sheep (NRC, 1985). The amount of protein in the feed concentrate was regulated with three different levels of supplementation: low protein (LP), moderate protein (MP), and high protein (HP). The protein content was calculated such that the MP group would have protein levels required to meet the protein requirements of finishing lambs (NRC, 1985). The three different diets were formulated to be composed of the same ingredients and to be 
isoenergetic, with a total digestive nutrient (TDN) concentration of $77 \%$; only the values of crude protein $(\mathrm{CP})$ content were varied among the three groups: $8.5 \%, 15 \%$, and $25 \%$, respectively, for the LP, MP, and HP diet groups (Table 1).

Table 1. Composition of the low protein (LP), moderate protein (MP), and high protein (HP) concentrates for supplementation of diet and percentages of crude protein (CP) and total digestive nutrients (TDN) of the concentrates.

\begin{tabular}{lccc}
\hline Ingredients & LP & MP & HP \\
\hline Corn grain ground & $90.05 \%$ & $75.05 \%$ & $48.85 \%$ \\
Wheat bran & $6.00 \%$ & $3.00 \%$ & $1.50 \%$ \\
Soybean meal & $0.80 \%$ & $18.80 \%$ & $46.20 \%$ \\
Vegetable fat & $0.20 \%$ & $0.45 \%$ & $1.20 \%$ \\
Limestone & $1.75 \%$ & $1.50 \%$ & $1.05 \%$ \\
Salt $(\mathrm{NaCl})$ & $0.50 \%$ & $0.50 \%$ & $0.50 \%$ \\
Mineral Premix & $0.70 \%$ & $0.70 \%$ & $0.70 \%$ \\
Total & $100.00 \%$ & $100.00 \%$ & $100.00 \%$ \\
CP & $8.58 \%$ & $14.99 \%$ & $24.98 \%$ \\
TDN & $77.02 \%$ & $77.00 \%$ & $76.99 \%$ \\
\hline
\end{tabular}

The feed concentrate was provided in the collective pens twice daily, in the early morning, before the animals were let out to pasture and in the late afternoon, when the animals were returned to the pens. The daily amount of concentrate offered was based on $3 \%$ of the average LW of the lambs of each of the groups. The amount of concentrate was adjusted each week according to the average weight of each group. Space at the feeders was sufficient for all the animals. In the pens, the animals had access to hay and water ad libitum.

\section{Productivity parameters}

The DWG was calculated as the difference in the LW between two evaluations divided by the number of days between the evaluations. The animals were weighed using manual scales.

\section{Parasitological parameters}

Feces were individually collected for the FECs (GORDON; WHITLOCK, 1939) in which each egg represented 50 epg; the feces were also used for larvae culture and identification (ROBERTS; O'SULLIVAN, 1950).

\section{Hematological parameter}

For the hematological and immunological analyses, blood was collected from the external jugular vein in $2 \mathrm{~mL}$ vacutainer tubes containing the anticoagulant, EDTA. Hematocrit (Ht) levels were evaluated by the microhematocrit method according to Jain (1986).

\section{Biochemical parameters}

Blood samples collected in tubes without the anticoagulant were centrifuged at $1,000 \mathrm{~g}$ for 8 minutes to separate the sera. The sera were used for evaluating concentrations of total protein, albumin, globulin, and urea. The samples were colorimetrically analyzed using a biochemical analyzer (Bio, 2000; Bioplus, Barueri, Brazil) and 
commercial kits (Labtest, Lagoa Santa, Brazil and Laborclin, Pinhais, Brazil). The globulin concentrations were calculated from the differences of the corresponding total protein and albumin concentrations.

\section{Statistical analyses}

Comparisons of the parasitological, hematological, biochemical, and productivity data of the three protein supplementation groups were performed by analysis of variance (ANOVA) with repeated measures, using the software Statgraphics $^{\circledR}$ Centurion XVI, version 16.1.11. (StatPoint Technologies, Inc., Warrenton, Virginia, USA), followed by Tukey's test with a 5\% level of significance. The values of epg were log transformed $[\log 10(x+1)]$ for statistical analysis. The values are presented in the results as the arithmetic mean \pm standard error of the untransformed data.

In the case of lambs with FEC greater than 10,000 epg that were treated with the anthelmintic, the epg values decreased to almost zero following treatment. For statistical analysis, to avoid the influence of these zero values on the group averages for the other analyses, the FEC value of the day of treatment plus the last FEC value before the use of the anthelmintic were used when computing the results for these lambs.

\section{Results}

The results of lots $\mathrm{A}$ and $\mathrm{B}$ are presented together, except for FEC for which significant differences were detected between the lots.

\section{Productivity parameters}

The average LWs of the lambs in the LP, MP, and HP groups at the beginning of the experiment
(D0) were $22.0 \pm 3.5,21.4 \pm 3.6$, and $21.1 \pm 3.2$ $\mathrm{kg}$, respectively, and at the end of the experiment (D98), average LWs were $46.4 \pm 7.7,48.3 \pm 7.7$, and $48.2 \pm 6.2 \mathrm{~kg}$, respectively; no significant differences were detected among the average LWs for the three groups at either the beginning or end of the experiment $(\mathrm{p}>0.05)$. During the 98 days of the study, the average weight of the animals of each group increased $(p<0.05)$. The average DWG of the three groups varied from 150 to $320 \mathrm{~g}$ per day, with an overall average of $250.4 \pm 51.6 \mathrm{~g}$ per day in the LP group, $276.5 \pm 71.1 \mathrm{~g}$ per day in the MP group, and $276.9 \pm 53.6 \mathrm{~g}$ per day in the HP groups; no significant differences were detected among the overall average DWG of the three groups ( $>0.05$ ).

\section{Parasitological parameters}

Coproparasitological examinations revealed eggs of strongylids, Strongyloides sp., Trichuris ovis, and Moniezia spp. and oocysts of Eimeria spp. Only the strongylid eggs were considered for further analysis.

At the beginning of the experiment (D0), the mean epg values of the animals of the three groups (LP, MP, and HP) were statistically similar ( $p>0.05$ ) in lot A and lot B (Table 2) and in both lots combined. A significant increase $(p<0.05)$ in the mean epg value was observed over time only in the LP group. By contrast, the mean epg values of the MP and HP groups on D98 were statistically similar to those on D0 (Table 2). The inter-group comparison of the mean epg values revealed no significant differences ( $p>0.05)$ among the animals of lot A. However, in the inter-group comparisons of lot B and both lots combined, the mean epg values of the LP group were significantly higher than those of the MP group from D42 onward. On D98, the MP group had the lowest average epg value, which was significantly different from that of the LP group $(\mathrm{p}<0.05)$ but similar to that of the HP group ( $>>0.05)$. 
Table 2. Mean and standard deviation values of the fecal egg counts (eggs per gram of feces, epg) of lambs fed different amounts of protein: low protein (LP), moderate protein (MP), and high protein (HP), according to the date of evaluation (D0 to D98).

\begin{tabular}{|c|c|c|c|}
\hline & \multicolumn{3}{|c|}{ Lot A } \\
\hline & $\begin{array}{c}\text { LP } \\
(\mathrm{n}=10)\end{array}$ & $\begin{array}{c}\text { MP } \\
(n=10)\end{array}$ & $\begin{array}{c}\text { HP } \\
(n=10)\end{array}$ \\
\hline D0 & $120.0 \pm 262.7^{\mathrm{aA}}$ & $190.0 \pm 337.3^{\mathrm{aA}}$ & $72.7 \pm 108.1^{\mathrm{aA}}$ \\
\hline D14 & $50.0 \pm 66.7^{\mathrm{aA}}$ & $55.0 \pm 55.0^{\mathrm{aA}}$ & $45.4 \pm 52.2^{\mathrm{aA}}$ \\
\hline $\mathrm{D} 28$ & $75.0 \pm 67.7 \mathrm{aA}$ & $130.0 \pm 137.8^{\mathrm{aA}}$ & $86.4 \pm 77.7^{\mathrm{aA}}$ \\
\hline D42 & $475.0 \pm 250.8^{\mathrm{aAB}}$ & $685.0 \pm 1055.4 \mathrm{aAB}$ & $410.0 \pm 558.7^{\mathrm{aAB}}$ \\
\hline D56 & $785.0 \pm 632.5 \mathrm{aAB}$ & $745.0 \pm 561.5 \mathrm{aAB}$ & $413.6 \pm 503.0 \mathrm{aAB}$ \\
\hline D70 & $1500.0 \pm 949.8 \mathrm{aBC}$ & $685.5 \pm 515.9$ аАв & $786.4 \pm 945.0$ аАв \\
\hline D84 & $1585.0 \pm 1290.8^{\mathrm{aBC}}$ & $1455.0 \pm 1628.3^{\mathrm{aB}}$ & $1168.2 \pm 1529.1 \mathrm{aB}$ \\
\hline \multirow[t]{3}{*}{ D98 } & $2310.0 \pm 2107.2^{\mathrm{aC}}$ & $1035.0 \pm 831.1^{\mathrm{aAB}}$ & $1009.1 \pm 1100.2^{\mathrm{aAB}}$ \\
\hline & \multicolumn{3}{|c|}{ Lot B } \\
\hline & $\begin{array}{c}\text { LP } \\
(n=10)\end{array}$ & $\begin{array}{c}\text { MP } \\
(n=10)\end{array}$ & $\begin{array}{c}\text { HP } \\
(\mathrm{n}=10)\end{array}$ \\
\hline D0 & $2030.0 \pm 1970.1^{\mathrm{aA}}$ & $910.0 \pm 953.3^{\mathrm{aA}}$ & $2638.9 \pm 2883.1^{\mathrm{aA}}$ \\
\hline D14 & $4320.0 \pm 5334.4^{\mathrm{aAB}}$ & $1820.0 \pm 2402.7^{\mathrm{aA}}$ & $3355.6 \pm 3942.1^{\mathrm{aA}}$ \\
\hline D28 & $7275.0 \pm 4999.5^{\mathrm{aAB}}$ & $3765.0 \pm 3555.0^{\mathrm{aA}}$ & $5177.8 \pm 4859.0^{\mathrm{aA}}$ \\
\hline D42 & $7765.0 \pm 5084.1 \mathrm{bAB}$ & $2805.0 \pm 3050.2^{\mathrm{aA}}$ & $4844.4 \pm 4775.7 \mathrm{abA}$ \\
\hline D56 & $8795.0 \pm 5444.4^{\mathrm{bAB}}$ & $3320.0 \pm 2864.9 \mathrm{aA}$ & $7566.7 \pm 4819.1 \mathrm{abA}$ \\
\hline D70 & $9185.0 \pm 6007.1^{\mathrm{bAB}}$ & $2631.2 \pm 2956.4 \mathrm{aA}$ & $5868.7 \pm 6327.5 \mathrm{abA}$ \\
\hline D84 & $9411.1 \pm 6840.9^{\mathrm{bAB}}$ & $2050.0 \pm 3053.8^{\mathrm{aA}}$ & $6037.5 \pm 6336.5^{\mathrm{abA}}$ \\
\hline D98 & $11220.0 \pm 9210.3^{\mathrm{bB}}$ & $2200.0 \pm 3619.5^{\mathrm{aA}}$ & $6400.0 \pm 6211.2^{\mathrm{abA}}$ \\
\hline
\end{tabular}

Different lowercase letters within a row and different uppercase letters within a column indicate significantly different values by Tukey's test (5\% significance level). The FEC values were transformed by $\log 10(\mathrm{x}+1)$ before statistical analysis. The data are represented as untransformed arithmetic means.

Lot A - lambs $(n=10)$ of each group treated with anthelmintic $\left(2.5 \mathrm{mg} \mathrm{kg}^{-1}\right.$ monepantel; Zolvix $\left.{ }^{\circledR}\right)$ at weaning

Lot $\mathrm{B}-\operatorname{lambs}(\mathrm{n}=10)$ of each group with no anthelmintic treatment at weaning.

Larval culture and identification revealed that $74.9-90 \%$ of recovered larvae were Haemonchus spp., 3-20.4\% Trichostrongylus spp., and 0-9.8\% Oesophagostomum spp., with no effect of diet protein supplementation.

Ten lambs were treated with anthelmintic (monepantel, $2.5 \mathrm{mg} \mathrm{kg}^{-1}$ ) because FEC values exceeded 10,000 epg. Six lambs from the LP group, 3 from the HP group, and 1 from the MP group were treated (all from lot B).

\section{Hematological parameter}

Figure 1 shows a progressive decrease in the average $\mathrm{Ht}$ values of the LP group from D0 to D98 $(p<0.05)$. However, in the MP and HP groups, no significant decrease $(p>0.05)$ occurred in the $\mathrm{Ht}$ values throughout the experiment. Inter-group comparison of the Ht levels revealed that, starting from D56, significant differences were detected among the groups in mean Ht levels $(p<0.05)$, with the values of the LP group always lower than those of the MP group. 
Figure 1. Mean values of the hematocrit (\%) of lambs fed different amounts of protein: low protein (LP), moderate protein (MP), or high protein (HP), according to the date of evaluation (D0 to D98).

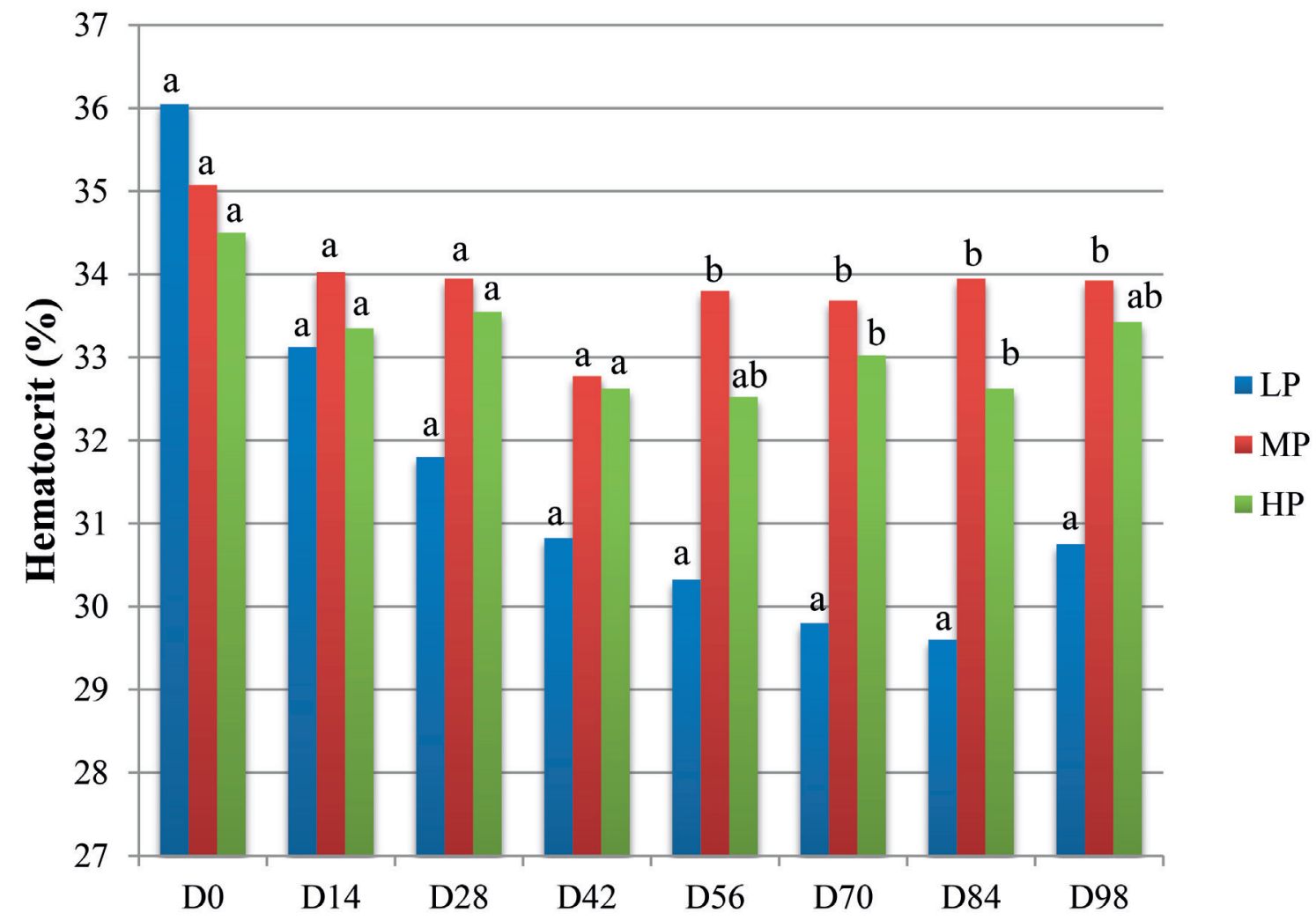

Different lowercase letters at each date indicate significantly different values among groups by Tukey's test (5\% significance level).

\section{Biochemical parameters}

The serum total protein concentrations are presented in Table 3. Only the HP group showed a significant increase $(\mathrm{p}<0.05)$ in the mean serum total protein concentration from D0 to D98.
The serum albumin concentration decreased from D0 to D98 only in the LP group ( $\mathrm{p}<0.05$; Figure $2)$. The serum globulin levels were significantly different among the three groups only on D14 $(\mathrm{p}<0.05)$. Over time, the mean serum globulin levels increased $(\mathrm{p}<0.05)$ in the LP and HP groups (Figure 2). 
Table 3. Mean and standard deviation values of the serum total protein concentrations $(\mathrm{g} / \mathrm{dL})$ of lambs fed different amounts of proteins: low protein (LP), moderate protein (MP), and high protein (HP), according to the date of evaluation (D0 to D98).

\begin{tabular}{|c|c|c|c|}
\hline & $\mathrm{LP}(\mathrm{n}=20)$ & $\mathrm{MP}(\mathrm{n}=20)$ & $\mathrm{HP}(\mathrm{n}=20)$ \\
\hline D0 & $5.3 \pm 1.2^{\mathrm{aA}}$ & $5.7 \pm 0.4^{\mathrm{bA}}$ & $5.3 \pm 0.4 \mathrm{aA}$ \\
\hline D14 & $5.3 \pm 0.7^{\mathrm{aA}}$ & $5.7 \pm 0.5^{\mathrm{aA}}$ & $5.4 \pm 0.6^{\mathrm{aAB}}$ \\
\hline D28 & $5.5 \pm 0.6^{\mathrm{aA}}$ & $5.8 \pm 0.4 \mathrm{aA}$ & $5.7 \pm 0.5 \mathrm{aAB}$ \\
\hline D42 & $5.3 \pm 0.5^{\mathrm{aA}}$ & $5.8 \pm 0.5^{\mathrm{bA}}$ & $5.7 \pm 0.6 \mathrm{abAB}$ \\
\hline D56 & $5.4 \pm 0.7 \mathrm{aA}$ & $5.8 \pm 0.6^{\mathrm{aA}}$ & $5.7 \pm 0.6 \mathrm{aAB}$ \\
\hline D70 & $5.5 \pm 0.6^{\mathrm{aA}}$ & $5.8 \pm 0.3^{\mathrm{aA}}$ & $5.8 \pm 0.5 \mathrm{aAB}$ \\
\hline D84 & $5.6 \pm 0.6^{\mathrm{aA}}$ & $5.9 \pm 0.4^{\mathrm{aA}}$ & $5.9 \pm 0.7 \mathrm{aAB}$ \\
\hline D98 & $5.6 \pm 0.6^{\mathrm{aA}}$ & $6.0 \pm 0.4 \mathrm{aA}$ & $5.8 \pm 0.5 \mathrm{aB}$ \\
\hline
\end{tabular}

Different lowercase letters within a row and different uppercase letters within a column indicate significantly different values by Tukey's test (5\% significance level).

Figure 2. Mean serum albumin (ALB) and globulin (GLO) concentrations $\left(\mathrm{g} \mathrm{dL}^{-1}\right)$ of lambs fed different amounts of protein: low protein (LP), moderate protein (MP), or high protein (HP), according to the date of evaluation (D0 to D98).

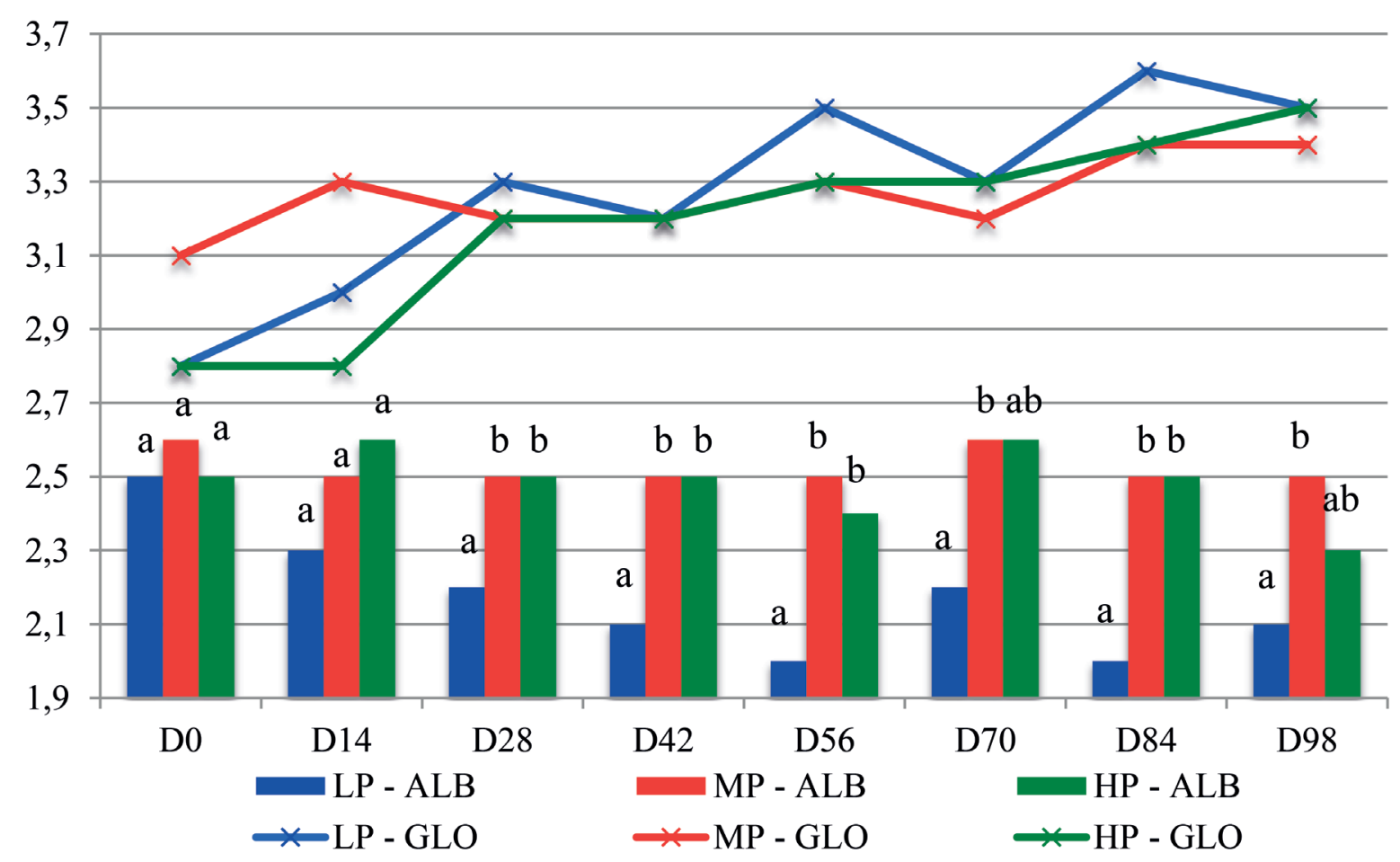

Different lowercase letters at each date indicate significantly different values among groups by Tukey's test ( $5 \%$ significance level). 
The average serum urea concentrations (Figure 3) increased significantly over time in the HP and MP groups, whereas those of the LP group decreased $(\mathrm{p}<0.05)$. Inter-group comparison revealed similar average serum urea concentrations among the three groups only on D0; from D14 onward, the values of the LP group were significantly lower than those of the MP group, which were lower than the values of the HP group $(\mathrm{p}<0.05)$.

Figure 3. Mean values of the serum urea concentrations $\left(\mathrm{g} \mathrm{dL}^{-1}\right)$ of lambs fed different amounts of protein: low protein (LP), moderate protein (MP), or high protein (HP), according to the date of evaluation (D0 to D98).

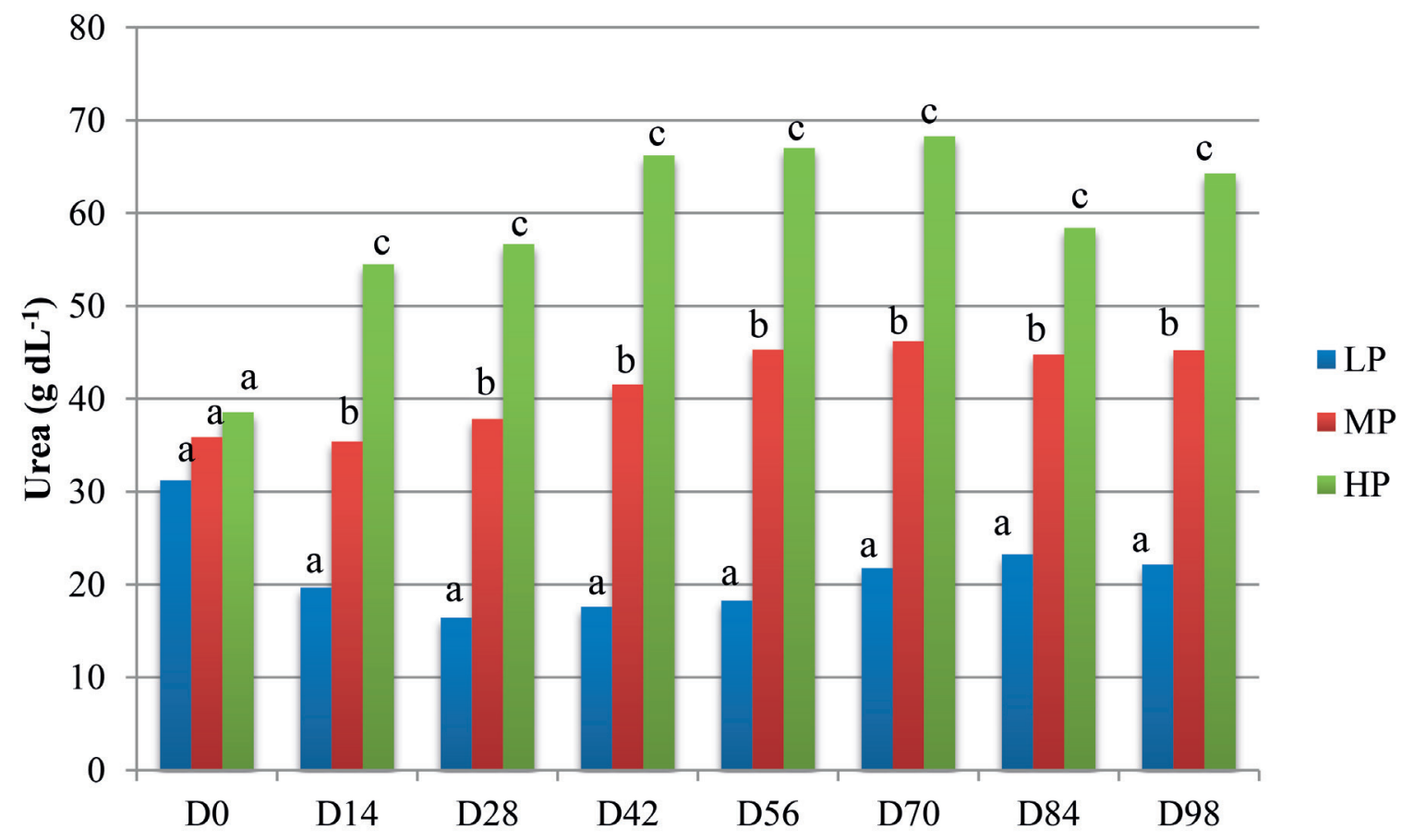

Different lowercase letters at each date indicate significantly different values among groups by Tukey's test (5\% significance level).

\section{Discussion}

In this study, protein supplementation influenced the resistance and resilience of lambs naturally infected with GINs, as previously demonstrated in other studies (COOP; KYRIAZAKIS, 1999; STRAIN; STEAR, 2001; BRICARELLO et al., 2005; LOUVANDINI et al., 2006; KHAN et al., 2012; CARVALHO et al., 2015).
The FEC is one of the more important parameters for defining the resistance of sheep to gastrointestinal parasites (ALBERS et al., 1987; GOOD et al., 2006; KELLY et al., 2013), and differences were observed among the three diet groups, indicating that protein supplementation increased the resistance of the lambs. The FEC values of the LP group increased significantly during the course of the experiment; however, no such increase was observed in the MP 
and HP groups. At the end of the experiment, the mean epg values of the LP group were significantly higher than those of the MP group; the epg values of the LP group were also higher than those of HP group, but the increase was not significant.

The differences observed in the FEC values between lots A and B must also be highlighted (Table 2 ), which suggested that protein supplementation for worm control was most valuable at high levels of infection. At low levels of infection (lot A), no differences were observed among the three groups (LP, MP, and HP), although the epg value increased significantly from D0 to D98 in the LP group. Louvandini et al. (2006) also observed that differences in the FEC between groups with high and low protein supplementation were only apparent when the epg values were higher. Increases in the requirements for metabolizable protein under parasitic infection for maintenance and to repair the tissue damage caused by the parasite provide a likely explanation for this difference (COOP; KYRIAZAKIS, 1999). Therefore, at low levels of infection, protein supplementation has no benefit, because the demand for protein does not increase. Similarly, Houdijk (2012) concluded that the magnitude of the improvement in host resistance following protein supplementation was dependent on the degree of protein scarcity in the absence of supplementation. However, importantly, in the present study, a control group without concentrate supplementation was not included for that comparison.

For the animals of the MP group, some of the parameters for resilience showed superior results. The Ht levels in animals of the LP group decreased significantly between D0 and D98. At the end of the experiment, the animals of the MP group had higher average Ht levels than those of the LP group, indicating that protein supplementation contributed to increased resilience (Figure 1). However, Ht levels in all three groups were within the normal range, given the reference range of $24-50 \%$ according to Jain (1986). In a recent study, Carvalho et al.
(2015) also demonstrated that animals that received supplemented diets had clearly improved resilience against infection, based on increased levels of $\mathrm{Ht}$ and weight gain.

The frequency of anthelmintic treatment (BISHOP, 2012), another measure of resilience, also showed that lambs of the LP group were less resilient, because this group represented $60 \%$ of the treated lambs, compared with the MP group, with only $10 \%$.

In studies by Haile et al. (2004) and Bricarello et al. (2005) on lambs infected with $H$. contortus, those receiving diets with high protein content showed fewer pathophysiological effects and less severe clinical signs than the animals receiving low protein supplementation. In the present study, the lower albumin levels observed in the LP group and the decrease in those values during the course of the experiment suggested that protein loss occurred because of the blood feeding of the parasite $H$. contortus (O'CONNOR et al., 2006). However, none of the animals presented clinical signs of worms despite high levels of infection. Apparently, the levels of protein supplementation, even in the LP group, were sufficient to prevent clinical signs of worm infection. Additionally, the albumin concentrations were within the reference range of values (2.40-3.00 $\left.\mathrm{g} \mathrm{dL}^{-1}\right)$, as proposed by Kaneko et al. (1997).

Similarly, increased globulin concentrations in the animals of the HP and LP groups might be related to the higher infection levels observed in these two groups at the end of the experiment. In the present study, the globulin concentrations in all three groups were within the reference range of values, 3.50-5.70 $\mathrm{g} \mathrm{dL}^{-1}$ (KANEKO et al., 1997).

Analysis of the productivity data revealed that the lambs supplemented with CP levels corresponding to $3 \%$ of body weight showed an average DWG of 250-279 g; which occurred even among the infected animals, and no differences were observed among the three diet groups. Bricarello et al. (2005), also 
studying the effect of the intake of 3\% body weight, but restricted to $75 \mathrm{~g}$ and $129 \mathrm{~g}$ of metabolizable protein, reported average DWG of $180 \mathrm{~g}$ and 270 $\mathrm{g}$, respectively; however, the animals fed the high protein diet showed significantly higher weight gain.

Schichowski et al. (2010) evaluated weaned lambs of different ages (between 6 and 13 weeks of age) with or without experimental infection with 5,000 H. contortus larvae. They observed that infection did not influence the DWG (range, 276$325 \mathrm{~g}$; diet with $19.5 \%$ CP supplement). Similar results were observed in the present study in which the DWG was high even among the infected animals. However, notably, of the 10 animals of lot B that required treatment with monepantel, $6(60 \%)$ were in the LP group. The treatment was administered between D14 and D35. In general, after treatment, the epg values of the animals decreased to as low as near zero. Although the pre-treatment values were considered for the statistical analyses of FECs, the same approach was not possible for the analysis of DWG. Therefore, the weight gain observed in the animals of the LP group could have possibly been lower because of the degree of infection had the lambs not been treated mid-experiment.

Despite the higher CP content diet, the animals of the HP group did not show superior DWG compared with the other groups. A possible explanation might be that part of the supplemented proteins was not used, with the excess excreted in the form of urea, as shown in Figure 3. Urea is a molecule that diffuses easily into the body tissues and is the primary form of metabolic nitrogen elimination in ruminants. In cases of energy deficiency and excess of degradable proteins, the rate of ammonia production exceeds that of its use by rumen microorganisms, which leads to an increase in the ammonia concentration in the rumen. Consequently, the excretion of urea increases, which increases the energy cost for urea synthesis and ultimately, translates into the loss of biological value of proteins (HUNTINGTON; ARCHIBEQUE, 1999). Therefore, when animals are fed diets with protein levels in excess of requirements, the excess proteins, rather than benefiting the animals, are excreted, in part. This excess is economically an unnecessary expense; moreover, in our study, the results of the HP group were similar to those of the LP group for some of the evaluated parameters, perhaps because of the adverse effects of excess ammonia and the energy requirement to remove it as urea (VAN SOEST, 1994).

\section{Conclusions}

The results of this study revealed that the lambs in the MP group supplemented with feed concentrate containing $15 \% \mathrm{CP}$, with an intake concentration of $3 \%$ of the LW, showed increased resistance to gastrointestinal parasites and resilience to the effects of these parasites based on lower epg values, higher hematocrit levels and albumin concentrations, and fewer number of animals treated with anthelmintics than those in the LP group.

Supplementation with feed concentrate containing $25 \% \mathrm{CP}$ is not recommended because no differences were detected between the animals of the HP and MP groups in their performance, as evaluated by the parameters of productivity or indicators of resistance and resilience. Additionally, the high levels of serum urea concentrations in the animals of the HP group could indicate the loss of excess protein.

The animals supplemented with feed concentrate with $8.5 \% \mathrm{CP}$, despite showing weight gain equivalent to that in the animals of the other groups, showed lower resistance and resilience, as determined from the high values of FEC, decreases in albumin and hematocrit levels and high number of animals treated with anthelmintics.

Cost analysis is required to define the optimum supplementation level. Based on the data presented in this study, at high levels of parasitic infection, protein supplementation will likely increase the resistance and resilience of lambs. 


\section{References}

ALBERS, G. A. A.; GRAY, G. D.; PIPER, L. R.; BARKER, J. S. F.; LE JAMBRE, L. F.; BARGER, I. A. The genetics of resistance and resilience to Haemonchus contortus infection in young Merino sheep. International Journal for Parasitology, Oxford, v. 17, n. 7, p. 13551363, 1987.

BISHOP, S. C. Possibilities to breed for resistance to nematode parasite infections in small ruminants in tropical production systems. Animal, New York, v. 6, n. 5, p. 741-747, 2012.

BISHOP, S. C.; STEAR, M. J. Modeling of host genetics and resistance to infectious diseases: understanding and controlling nematode infections. Veterinary Parasitology, Amsterdam, v. 115, n. 2, p. 147-166, 2003.

BRICARELLO, P. A.; AMARANTE, A. F. T.; ROCHA, R. A.; CABRAL FILHO, S. L.; HUNTLEY, J. F.; HOUDIJK, J. G. M.; ABDALLA, A. L.; GENNARI, S. $\mathrm{M}$. Influence of dietary protein supply on resistance to experimental infections with Haemonchus contortus in Ile de France and Santa Ines lambs. Veterinary Parasitology, Amsterdam, v. 134, n. 1-2, p. 99-109, 2005.

CARVALHO, N.; NEVES, J. H. D.; NAZATO, C.; LOUVANDINI, H.; AMARANTE, A. F. T. The effects of diet and corticosteroid-induced immune suppression during infection by Haemonchus contortus in lambs. Veterinary Parasitology, Amsterdam, v. 214, n. 3-4, p. 289-294, 2015.

CINTRA, M. C. R.; TEIXEIRA, V. N.; NASCIMENTO, L. V.; SOTOMAIOR, C. S. Lack of efficacy of monepantel against Trichostrongylus colubriformis in sheep in Brazil. Veterinary Parasitology, Amsterdam, v. 216, p. 4-6, 2016.

COOP, R. L.; KYRIAZAKIS, I. Nutrition-parasite interaction. Veterinary Parasitology, Amsterdam, v. 84, n. 3-4, p. 187-204, 1999.

DATTA, F. U.; NOLAN, J. V.; ROWE, J. B.; GRAY, G. D.; CROOK, B. J. Long-term effects of short-term provision of protein-enriched diets on resistance to nematode infection, and live-weight gain and wool growth in sheep. International Journal for Parasitology, Amsterdam, v. 29, n. 3, p. 479-488, 1999.

GOOD, B.; HANRAHAN, J. P.; CROWLEY, B. A.; MULCAHY, G. Texel sheep are more resistant to natural nematode challenge than Suffolk sheep based on faecal egg count and nematode burden. Veterinary Parasitology, Amsterdam, v. 136, n. 3-4, p. 317-327, 2006.

GORDON, H. M.; WHITLOCK, H. V. A new technique for counting nematode eggs in sheep faeces. Journal of the Council for Scientific and Industrial Research, New Delhi, v. 12, n. 1, p. 50-52, 1939.

HAILE, A.; ANINDO, D. O.; TEMBELY, S.; MUKASAMUGERWA, E.; TIBBO, M.; YAMI, A.; BAKER, R. L.; REGE, J. E. O. Effects of dietary protein supplementation and infection with gastrointestinal nematode parasites on some nutritional and metabolic parameters in Ethiopian Menz and Horro sheep. Livestock Production Science, Amsterdam, v. 91, n. 1-2, p. 183-195, 2004.

HOSTE, H.; TORRES-ACOSTA, J. F. J. Non chemical control of helminths in ruminants: adapting solutions for changing worms in a changing world. Veterinary Parasitology, Amsterdam, v. 180, n. 1-2, p. 144-154, 2011.

HOUDIJK, J. G. M. Differential effects of protein and energy scarcity on resistance to nematode parasites. Small Ruminant Research, Amsterdam, v. 103, n. 1, p. 41-49, 2012.

HUNTINGTON, G. B.; ARCHIBEQUE, S. L. Practical aspects of urea and ammonia metabolism in ruminants. Proceedings of the American Society of Animal Science, Raleigh, p.1-11, 1999.

JAIN, N. C. Schalm's veterinary hematology. Philadelphia: Lea \& Febiger, 1986. 1232 p.

KAHN, L. P.; WOODGATE, R. G. Integrated parasite management: products for adoption by the Australian sheep industry. Veterinary Parasitology, Amsterdam, v. 186, n. 1-2, p. 58-64, 2012.

KANEKO, J. J.; HARVEY, D. W.; BRUSS, W. L. Clinical biochemistry of domestic animals. $5^{\text {th }}$ ed. New York: Academic Press, 1997. 932 p.

KELLY, G. A.; KAHN, L. P.; WALKDEN-BROWN, $\mathrm{S}$. W. Measurement of phenotypic resilience to gastrointestinal nematodes in Merino sheep and association with resistance and production variables. Veterinary Parasitology, Amsterdam, v. 193, n. 1-3, p. 111-117, 2013.

KHAN, F.A.; SAHOO, A.; SONAWANE, G. G.; KARIM, S. A.; DHAKAD, S.; PAREEK, A. K.; TRIPATHI, B. N. Effect of dietary protein on responses of lambs to repeated Haemonchus contortus infection. Livestock Science, Amsterdam, v. 150, n. 1-3, p. 143-151, 2012.

LOUVANDINI, H.; VELOSO, C. F. M.; PALUDO, G. R.; DELL'PORTO, A.; GENNARI, S. M.; MCMANUS, C. M. Influence of protein supplementation on the resistance and resilience on young hair sheep naturally infected with gastrointestinal nematodes during rainy and dry seasons. Veterinary Parasitology, Amsterdam, v. 137, n. 1-2, p. 103-111, 2006. 
NATIONAL RESEARCH COUNCIL - NRC. Nutrient requirements of sheep. $6^{\text {th }}$ ed. Washington: National Academy Press, 1985.

O'CONNOR, L. J.; WALKDEN-BROWN, S. W.; KAHN, L. P. Ecology of the free-living stages of major trichostrongylid parasites of sheep. Veterinary Parasitology, Amsterdam, v. 142, n. 1-2, p. 1-15, 2006.

PAPADOPOULOS, E. Anthelmintic resistance in sheep nematodes. Small Ruminant Research, Amsterdam, v. 76, n. 1-2, p. 99-103, 2008.

ROBERTS, F. H. S.; O'SULLIVAN, P. J. Methods for egg counts and larval cultures for strongyles infesting the gastro-intestinal tract of cattle. Australian Journal of Agricultural Research, Clayton South, v. 1, n. 1, p. 99102, 1950.

ROSE, H.; RINALDI, L.; BOSCO, A.; MAVROT, F.; DE WAAL, T.; SKUCE, P.; CHARLIER, J.; TORGERSON, P. R.; HERTZBERG, H.; HENDRICKX, G.; VERCRUYSSE, J.; MORGAN, E. R. Widespread anthelmintic resistance in European farmed ruminants: a systematic review. Veterinary Record, London, v. 176, n. 21, p. 546-548, 2015.

SCHICHOWSKI, C.; MOORS, E.; GAULY, M. Influence of weaning age and an experimental Haemonchus contortus infection on behaviour and growth rates of lambs. Applied Animal Behaviour Science, Amsterdam, v. 125, n. 3-4, p. 103-108, 2010.

SCOTT, I.; POMROY, W. E.; KENYON, P. R.; SMITH, G.; ADLINGTON, B.; MOSS, A. Lack of efficacy of monepantel against Teladorsagia circumcincta and Trichostrongylus colubriformis. Veterinary Parasitology, Amsterdam, v. 198, n. 1-2, p. 166-171, 2013.
STRAIN, S. A. J.; STEAR, M. J. The influence of protein supplementation on the immune response to Haemonchus contortus. Parasite Immunology, Hoboken v. 23, n. 10, p. 527-531, 2001.

THOMAZ-SOCCOL, V.; SOUZA, F. P.; SOTOMAIOR, C.; CASTRO, E. A.; MILCZEWSKI, V.; MOCELIN, G.; SILVA, M. C. P. Resistance of gastrointestinal nematodes to anthelmintics in sheep (Ovis aries). Brazilian Archives of Biology and Technology, Curitiba, v. 47, n. 1, p. 41-47, 2004.

TORRES-ACOSTA, J. F. J.; MENDOZA-DE-GIVES, P.; AGUILAR-CABALLERO, A. J.; CUÉLLAR-ORDAZ, J. A. Anthelmintic resistance in sheep farms: update of the situation in the American continent. Veterinary Parasitology, Amsterdam, v. 189, n. 1, p. 89-96, 2012a.

TORRES-ACOSTA, J. F. J.; SANDOVAL-CASTRO, C. A.; HOSTE, H.; AGUILAR-CABALlERO, A. J.; CÁMARA-SARMIENTO, R.; ALONSO-DÍAZ, M. A. Nutritional manipulation of sheep and goats for the control of gastrointestinal nematodes under hot humid and subhumid tropical conditions. Small Ruminant Research, Amsterdam, v. 103, n. 1, p. 28-40, 2012 b.

VAN DEN BROM, R.; MOLL, L.; KAPPERT, C.; VELLEMA, P. Haemonchus contortus resistance to monepantel in sheep. Veterinary Parasitology, Amsterdam, v. 209, n. 3-4, p. 278-280, 2015.

VAN SOEST, P. J. Nutritional ecology of the ruminant. Ithaca: Cornell University Press, 1994. 476 p. 
